\title{
John Delwyn Thomas
}

This Obituary of John Delwyn Thomas (BMJ 2015;351:h5922, doi:10.1136/bmj.h5922) contains an error.

In the submitted original copy, the fourth sentence read: "His national service was with the Royal Army Medical Corps in

Hong Kong, where he met his future wife, who was a QA nurse." This means, of course, that she was a member of Queen Alexandra's Royal Army Nursing Corps-nothing to do with quality assurance, as the obituaries editor assumed.

Cite this as: BMJ 2016;352:1635

๑ BMJ Publishing Group Ltd 2016 